\title{
ANALISIS VARIABEL KUALITAS PELAYANAN TERHADAP KEPUASAN KONSUMEN PADA SWALAYAN CITROULI BABARSARI YOGYAKARTA
}

\author{
Ade Ryan Shaputra \\ aderyanshaputra@gmail.com \\ Universitas Ahmad Dahlan \\ Fitroh Adhilla \\ fitauad@yahoo.com \\ Universitas Ahmad Dahlan
}

\begin{abstract}
ABSTRAK
This study aims to determine and analyze variables quality of service (X) to customer satisfaction (Y), simultaneously or together with customer satisfaction at Citrouli Supermarket Babarsari in Yogyakarta. The sample used in this study totaling 100 respondents. The sampling method with using purposive sampling. Data analysis method used is a quantitative analysis using the validity test and test reliability, F test, coefficient of determination, $\mathrm{t}$ test and multiple regression analysis. By using the method of multiple linear regression analysis can be it was concluded that the physical aspect variables had a positive effect on consumer satisfaction with a B value of 0.080 and an increase of 1 unit then the value of the physical aspects increases by 0.080 , the reliability variable is influential positive on consumer satisfaction with a B value of 0.231 and increases by 1 unit then the reliability variable increases by 0.231 , variable personal interaction has a positive effect on customer satisfaction with B value of 0.159 and increased by 1 unit then the personal interaction variable increased 0.159 , the problem solving variable has a positive effect on consumer satisfaction with a B value of 0.241 and increased by 1 unit then the variable customer satisfaction increases 0.241 , the policy variable positive effect on customer satisfaction with a $B$ value of 0.267 and increase by 1 unit, the policy variable increases by 0.267 . The resulting determination coefficient is 0.572 yang means that $57.2 \%$ of customer satisfaction variables can be explained by variables Physical Aspects (X1), Reliability (X2), Personal Interaction (X3), Solving problems (X4) and Policies (X5) together, while the rest of $42.8 \%$ explained by other variables not contained in this research.
\end{abstract}

Keywords: Physical Aspect; Reliability; Personal Interaction; Problem Solving; Policies; Customer Satisfaction.

\section{PENDAHULUAN}

Kemajuan dibidang perekonomian selama ini telah banyak membawa akibat perkembangan yang pesat dalam bidang usaha. Sejalan dengan hal tersebut banyak bermunculan perusahaan dagang yang bergerak pada bidang perdagangan eceran (retailing) yang berbentuk toko, mini market, departement store (toserba), pasar swalayan (supermarket) dan lain-lain. Hal tersebut akan menimbulkan persaingan di antara perusahan-perusahaan tersebut. Agar perusahaan dapat memenangkan persaingan tersebut mereka memanfaatkan peluang-peluang bisnis yang ada dan berusaha untuk menerapkan strategi pemasaran yang tepat dalam rangka untuk menguasai pasar.

Tujuan utama ini juga diiringi dengan tujuan-tujuan lain yang lebih sempit seperti meningkatkan penjualan, meningkatkan pangsa pasar, melakukan komunikasi dan promosi yang lebih baik, 
serta memperkuat citra. Tujuan-tujuan ini memang bisa saja dicapai dengan pemasaran masal (mass marketing), tetapi era monopoli sudah berakhir dan perusahaan dengan pemasaran masal akan kesulitan untuk bersaing dengan perusahaan lain (Lopiyoadi, 2006).

Merebut pangsa pasar dapat tercapai apabila perusahaan itu mampu mengetahui seberapa besar kepuasan yang didapatkan konsumen. Yang dimaksud dengan kepuasan adalah perasaan senang atau kecewa seseorang yang muncul setelah membandingkan kinerja (hasil) produk yang dipirkan terhadap kinerja (hasil) produk dipikirkan terhadap kinerja (hasil) yang diharapkan (Kotler, 2007). Menurut Schanaars (dalam Tjiptono, 2000) kepuasan pelanggan merupakan salah satu kunci keberhasilan suatu usaha, hal ini dikarenakan dengan memuaskan konsumen, organisasi atau perusahaan dapat meningkatkan tingkat keuntunganya dan mendapatkan pangsa pasar yang lebih luas.

Kini semakin disadari bahwa kepuasan konsumen merupakan aspek vital dalam rangka bertahan dan memenangkan persaingan. Kepuasan merupakan reaksi emosional jangka pendek pelanggan terhadap kinerja jasa tertentu (Lovelock, 2007). Kepuasan pelanggan akan tercapai jika faktor utama dari pelayanan tersebut tersedia, yaitu kesiapan sumber daya manusia dalam melayani calon pelanggan (Kasmir, 2005). Kepuasan pelanggan ditentukan oleh kualitas produk dan kualitas layanan yang dikehendaki pelanggan sehingga jaminan dari kualitas yang diberikan menjadi prioritas bagi perusahaan (Hidayat, 2009).

Maka dari itu perusahaan harus terlibat langsung dalam pemenuhan kebutuhan dan kepuasan konsumen, hal ini harus mendapat prioritas pertama dibanding dengan mendapat pelanggan baru, upaya yang dilakukan memuaskan konsumen terhadap keberhasilan badan usaha untuk mencapai tujuan tergantung bagaimana pasar membuat tanggapan kepuasan konsumen terpenuhi.

Kotler (2007) mendefinisikan pemasaran dalam lingkup sosial adalah sebagai berikut: "Pemasaran adalah suatu proses sosisal yang didalamnya terdapat individu dan kelompok mendapatkan apa yang mereka butuhkan dan inginkan dengan menciptakan, menawarkan dan secara bebas mempertukarkan produk yang bernilai dengan pihak lain. Dari definisi tersebut dapat disimpulkan bahawa perusahaan berusaha menawarkan derajat kepuasan yang memenuhi harapan konsumen, bagi perusahaan yang menggunakan konsep yang orientasinya untuk masyarakat, diharapkan mampu mengantisipasi berbagai faktor yang dapat mempengaruhi daya beli konsumen, sehingga konsumen merasa puas dan senang berbelanja di swalayan tersebut. Konsumen membeli barang atau jasa adalah untuk memuaskan berbagai keinginan dan kebutuhanya, karena itu penting bagi perusahaan untuk mengetahui dan mempelajari faktor-faktor yang mempengaruhi kepuasan konsumen dari pasar sasaran yang dituju agar produk yang dihasilkan mendapat tanggapan yang efektif.

Menurut Lovelock (2007) kualitas pelayanan jasa merupakan evaluasi kognitif jangka panjang pelanggan terhadap penyerahan jasa suatu perusahaan. Pada umumnya pelayanan yang diberikan perusahaan baik akan meghasilkan kepuasan yang tinggi serta pembelian ulang yang sangat tinggi pula. Parasuraman (dalam Lupiyoadi, 2008) kualitas pelayanan jasa dapat dilihat dari lima dimensi antara lain: bukti langsung (tangible), keandalan (reliability), ketanggapan (responsiveness), jaminan (assurance) dan empati (emphaty).

Tujuan dari penelitian ini di antaranya untuk mengetahui variabel kualitas pelayanan (physical aspect/aspek fisik, reliability/keandalan, personal interaction/interaksi pribadi, problem solving/pemecahan masalah, dan 
policy/kebijakan) secara parsial berpengaruh signifikan terhadap kepuasan pelanggan Swalayan Citrouli Babarsari dan untuk mengetahui variabel kualitas pelayanan (physical aspect/aspek fisik, reliability/keandalan, personal interaction/interaksi pribadi, problem solving/pemecahan masalah, dan policy/kebijakan) secara serempak berpengaruh signifikan terhadap kepuasan pelanggan Swalayan Citrouli Babarsari.

\section{REVIEW LITERATUR DAN HIPOTESIS}

\section{Landasan Teori}

1. Kepuasan Konsumen

Kepuasan adalah perasaan senang atau kecewa seseorang yang muncul setelah membandingkan kinerja (hasil) produk yang dipikirkan terhadap kinerja (hasil) yang diharapkan (Kotler, 2007).

2. Kualitas Pelayanan

Definisi kualitas pelayanan menurut Lupiyoadi (2006) adalah seberapa jauh perbedaan antara kenyataan dan harapan pelanggan atas layanan yang mereka terima atau peroleh. Dalam mengevaluasi kepuasan konsumen terhadap produk, jasa atau perusahaan tertentu, konsumen umumnya mengacu pada faktor atau dimensi.

3. Aspek Fisik (Physical Aspects) yang meliputi toko memiliki peralatan dan perlengkapan yang modern, fasilitas fisik toko menarik secara visual, toko memiliki tas belanja, troly, atau katalog yang menarik, suasana toko bersih, menarik, nyaman di setiap tempat, termasuk di toilet dan kamar pas, tata letak toko memudahkan pelanggan untuk menemukan apa yang mereka butuhkan dan tata letak toko memudahkan pelanggan untuk bergerak di dalam toko.
4. Keandalan (Reliability) yang meliputi toko memiliki komitmen yang kuat untuk menepati janji atau sesuai dengan yang diiklankan, toko memberikan pelayanan yang baik sesuai yang dijanjikan, toko melakukan pelayanan yang benar sejak pertama kali, toko ini memiliki barang dagangan yang tersedia saat pelanggan menginginkannya serta toko bebas dari kesalahan dalam transaksi penjualan dan pencatatan.

5. Interaksi Pribadi (Personal Interaction) terdiri dari karyawan toko memiliki pengetahuan untuk menjawab pertanyaan pelanggan, perilaku karyawan toko menanamkan kepercayaan pada pelanggan, pelanggan merasa aman melakukan transaksi dengan toko, karyawan toko memberikan layanan yang tepat untuk pelanggan, karyawan toko selalu siap untuk merespon permintaan pelanggan, toko memberikan perhatian secara individual pada pelanggan, karyawan toko selalu konsisten untuk melayani pelanggan dengan sopan, karyawan toko bersedia dan antusias untuk menanggapi permintaan pelanggan, toko menyediakan lingkungan yang kondusif bagi pelanggan untuk berkomunikasi dengan pembeli lain atau dengan karyawan toko, toko menyediakan lingkungan yang kondusif untuk kontak sosial dengan pembeli lain atau karyawan toko dan toko menyediakan lingkungan yang kondusif untuk mengenal dan berhubungan dengan pembeli lain atau karyawan toko.

6. Pemecahan Masalah (Problem Solving) terdiri dari karyawan toko menunjukan minat dan tulus memecahkan masalah apabila pelanggan mengalami masalah yang berhubungan dengan toko dan karyawan toko mampu menangani keluhan pelanggan dengan cepat dan segera. 
7. Kebijakan (Policy) terdiri dari toko menawarkan barang-barang dengan kualitas baik, toko menyediakan tempat parker yang luas, aman, dan nyaman untuk pelanggan, toko memiliki jam operasional yang sesuai dengan keinginan pelanggan, toko menerima pembayaran melalui kartu kredit dan toko mampu dan rela menerima kembali barang rusak yang terbeli pelanggan dan menukarnya dengan barang yang baru.

\section{Penelitian Terdahulu}

Penelitian terdahulu pernah dilakukan oleh Dwi Cahyanto (2015) dengan judul "ANALISIS KUALITAS PELAYANAN TERHADAP KEPUASAN KONSUMEN PADA SWALAYAN PAMELA 1 DI YOGYAKARTA", bahwa variabel tampilan fisik tidak berpengaruh signifikan terhadap kepuasan konsumen dengan nilai signikansi ( $\mathrm{P}$ value) sebesar $0.063>0.05$, variabel kehandalan tidak berpengaruh signifikan terhadap kepuasan konsumen dengan nilai signifikansi (P value) sebesar $0.688>0.05$, variabel daya tanggap berpengaruh signifikan terhadap kepuasan konsumen dengan nilai signifikan ( $\mathrm{P}$ value) sebesar $0.013<0.05$, variabel jaminan berpengaruh signifikan terhadap kepuasan konsumen dengan nilai signifikan ( $\mathrm{P}$ value) sebesar $0.009<0.05$, variabel empati tidak berpengaruh signifikan terhadap kepuasan konsumen dengan nilai signifikan ( $\mathrm{P}$ value) sebesar $0.428>0.05$. Koefisien determinasi yang dihasilkan adalah sebesar 0.236 yang berarti $23.6 \%$ variabel kepuasan konsumen dijelaskan oleh variabel Tampilan Fisik (X1), Kehandalan (X2), Daya tanggap (X3), Jaminan (X4) dan Empati (X5) secara bersama-sama, sedangkan sisanya sebesar $76.4 \%$ dijelaskan oleh variabel lain yang tidak terdapat dalam penelitian ini.

\section{Hipotesis}

H1: Ada pengaruh antara kualitas pelayanan pada dimensi aspek fisik (Physical aspect) terhadap kepuasan konsumen pada Swalayan Citrouli Babarsari di Yogyakarta.

H2: Ada pengaruh antara kualitas pelayanan pada dimensi keandalan (Reliability) terhadap kepuasan konsumen pada Swalayan Citrouli Babarsari di Yogyakarta.

H3: Ada pengaruh antara kualitas pelayanan pada dimensi interaksi pribadi (Personal interaction) terhadap kepuasan konsumen pada Swalayan Citrouli Babarsari di Yogyakarta.

H4: Ada pengaruh antara kualitas pelayanan pada pemecahan masalah (Problem solving) terhadap kepuasan konsumen pada Swalayan Citrouli Babarsari di Yogyakarta.

H5: Ada pengaruh antara kualitas pelayanan pada dimensi kebijakan (Policy) terhadap kepuasan konsumen pada Swalayan Citrouli Babarsari di Yogyakarta.

\section{METODE PENELITIAN}

\section{Populasi dan Sampel}

Populasi adalah generalisasi yang terdiri atas obyek atau subyek yang mempunyai kualitas dan karakteristik tertentu yang ditetapkan oleh peneliti untuk dipelajari dan kemudian ditarik kesimpulanya (Sugiyono, 2008). Adapun populasi dalam penelitian ini adalah seluruh konsumen yang berbelanja atau membeli produk pada Swalayan Citrouli babarsari di Yogyakarta.

Sampel adalah bagian dari jumlah dan karakteristik yang dimiliki oleh populasi. Bila populasi besar, dan peneliti tidak mungkin mempelajari semua yang ada pada populasi, misalnya karena 
keterbatasan, tenaga dan waktu, maka peneliti dapat menggunakan sampel yang diambil dari populasi tersebut (Sugiyono, 2008).

Metode pengambilan sampel dalam penelitian ini dilakukan dengan cara Accidental Sampling dan menggunakan Purposive Sampling yang merupakan bagian dari non probability sampling. Bentuk pengambilan sampel ini berdasarkan kebetulan, yaitu siapa saja yang bertemu dengan peneliti dan dianggap cocok sebagai sumber data akan menjadi sampel penelitian ini (Sugiyono, 2014) yaitu semua maysarakat yang berbelanja di Swalayan Citrouli Babarsari.

\section{Uji Instrumen}

\section{Uji Validitas}

Menurut Sugiyono (2014) uji keabsahan data dalam penelitian, sering hanya ditekankan pada uji validitas dan reliabilitas. Dalam penelitian kuantitatif, kriteria utama terhadap data hasil penelitian adalah valid, reliabel dan obyektif. Validitas merupakan derajat ketepatan antara data yang terjadi pada obyek penelitian dengan daya yang dapat dilaporkan oleh peneliti. Dengan demikian data yang valid adalah data "yang tidak berbeda" antara data yang dilaporkan oleh peneliti dengan data yang sesungguhnya terjadi pada obyek penelitian. Kalau dalam obyek penelitian terdapat warna merah, maka penelitian akan melaporkan warna merah, kalau dalam obyek penelitian para pegawai bekerja dengan keras, maka peneliti melaporkan bahwa pegawai bekerja dengan keras. Bila peneliti membuat laporan yang tidak sesuai dengan apa yang terjadi pada obyek, maka data tersebut dapat dinyatakan tidak valid.

\section{Uji Reliabilitas}

Menurut Susan Stainback dalam Sugiyono (2014:267) menyatakan bahwa Reliabilitas berkenaan dengan derajad konsistensi dan stabilitas data Atau temuan. Dalam pandangan positivistik (kuantitatif), suatu data dinyatakan reliabel apabila dua atau lebih peneliti dalam obyek yang sama menghasilkan data yang sama, atau peneliti sama dalam waktu berbeda menghasilkan data yang sama, atau sekelompok data bila dipecah menjadi dua menunjukkan data yang tidak berbeda. Kalau peneliti satu menemukan dalam obyek berwarna merah, maka peneliti yang lain juga demikian. Karena reliabilitas berkenaan dengan derajad konsistensi, maka bila ada peneliti lain mengulangi atau mereplikasi dalam penelitian pada obyek yang sama dengan metode yang sama maka akan menghasilkan data yang sama. Pengujian instrumen penelitian dengan sampel sejumlah 30 responden. Koefisien reliabilitas ditunjukan oleh koefisien cronbach alpha yang berkisar antara 0 sampai 1 . Semakin tinggi nilai koefisien cronbach alpha berarti semakin tinggi reliabilitas alat ukur yang digunakan. Untuk menguji reliabilitas dalam penelitian ini adalah dengan membandingkan cronbach coefficient alpha ( $\mathrm{r}$ alpha) pada hasil olahan SPSS Release 20.0 dengan rule of thumb atau kesepakatan umum dari koefisien alpha yaitu lebih besar dari 0.6 untuk penelitian eksploratori.

\section{Teknik Analisis Data}

1. Analisis Regresi Berganda

Menurut Algifari (2014) model regresi linear untuk menganalisis hubungan pengaruh suatu variabel independen numerik (X) terhadap variabel dependen (Y) dalam mengukur skala interval dan skala rasio. Model regresi tersebut kemudian digunakan untuk menentukan taksiran nilai variabel dependen ( $Y$ ) pada nilai variabel independen (X) tertentu. Penerapan model regresi dalam banyak 
praktik membutuhkan suatu model regresi estimasi yang dapat digunakan untuk menghasilkan nilai estimasi yang menggunakan lebih dari satu variabel independen (X). Artinya nilai variabel dependen (Y) tidak hanya dipengaruhi oleh satu variabel independen (X) saja.

\section{Uji Hipotesis}

\section{Uji Parsial (Uji T)}

Menurut Suharyadi (2010) uji signifikansi parsial atau individual digunakan untuk menguji apakah suatu variabel bebas berpengaruh atau tidak terhadap variabel terikat.

\section{Uji Simultan (Uji F)}

Menurut Suharyadi (2010) uji global disebut juga uji signifikansi serentak atau uji f. Uji ini dimaksudkan untuk melihat kemampuan menyeluruh dari variabel bebas dapat atau mampu menjelaskan tingkah laku atau keragaman variabel terikat (Y).

\section{Uji Koefisien Determinasi}

Menurut Suharyadi (2010) koefisien korelasi (R) menunjukkan seberapa dekat titik kombinasi antara variabel dependen atau variabel terikat (Y) dengan variabel independen.

\section{HASIL PENELITIAN DAN PEMBAHASAN}

\section{Hasil Penelitian}

1. Hasil Uji Validitas

\begin{tabular}{|l|c|c|c|c|c|c|c|}
\hline \multicolumn{7}{|c|}{ Hasil Uji Validitas } \\
\begin{tabular}{|l|c|c|c|c|c|c|}
\hline \multicolumn{1}{|c|}{ Nama } \\
Indikator
\end{tabular} & \multicolumn{7}{c|}{ Komponen Faktor } \\
\hline & 1 & 2 & 3 & 4 & 5 & 6 & \\
\hline Aspek Fisik 1 & 0,873 & & & & & & Valid \\
\hline Aspek Fisik 2 & 0,881 & & & & & & Valid \\
\hline Aspek Fisik 3 & 0,805 & & & & & & Valid \\
\hline Keandalan 1 & & 0,805 & & & & & Valid \\
\hline Keandalan 2 & & 0,802 & & & & & Valid \\
\hline Keandalan 3 & & 0,739 & & & & & Valid \\
\hline $\begin{array}{l}\text { Interaksi } \\
\text { Pribadi 1 }\end{array}$ & & & 0,795 & & & & Valid \\
\hline $\begin{array}{l}\text { Interaksi } \\
\text { Pribadi 2 }\end{array}$ & & & 0,876 & & & & Valid \\
\hline $\begin{array}{l}\text { Interaksi } \\
\text { Pribadi 3 }\end{array}$ & & & 0,817 & & & & Valid \\
\hline $\begin{array}{l}\text { Pemecahan } \\
\text { Masalah 1 }\end{array}$ & & & & 0,917 & & & Valid \\
\hline $\begin{array}{l}\text { Pemecahan } \\
\text { Masalah 2 }\end{array}$ & & & & 0,910 & & & Valid \\
\hline $\begin{array}{l}\text { Pemecahan } \\
\text { Masalah 3 }\end{array}$ & & & & 0,283 & & & Valid \\
\hline Kebijakan 1 & & & & & 0,717 & & Valid \\
\hline Kebijakan 2 & & & & & 0,893 & & Valid \\
\hline Kebjiakan 3 & & & & & 0,604 & & Valid \\
\hline $\begin{array}{l}\text { Kepuasan } \\
\text { Konsumen 1 }\end{array}$ & & & & & & 0,880 & Valid \\
\hline \begin{tabular}{l|l|l|l|l|l|c|} 
Kepuasan \\
Konsumen 2
\end{tabular} & & & & & & 0,775 & Valid \\
\hline $\begin{array}{l}\text { Kepuasan } \\
\text { Konsumen 3 }\end{array}$ & & & & & & 0,735 & Valid \\
\hline $\begin{array}{l}\text { Kepuasan } \\
\text { Konsumen 4 }\end{array}$ & & & & & & 0,925 & Valid \\
\hline
\end{tabular}

a. Uji validitas variabel Aspek Fisik 1.

Tabel Component Matrix pada hasil output SPSS terlihat bahwa terbentuk 3 component, sementara yang diharapkan hanya 1 komponen, artinya dari ketiga indikator yaitu Aspek Fisik 1, Aspek Fisik 2 dan Aspek Fisik 3 tersebut valid. Jadi jika indikator-indikator tersebut valid, maka hanya terbentuk satu component yaitu faktor tampilan fisik. Indikatorindikator yang akan dikeluarkan adalah indikator-indikator yang memiliki MSA (Measure of sampling Adequancy) yang di bawah 0,5 dengan memperhatikan tabel Anti-Images Matrices pada output SPSS.

b. Uji validitas variabel Keandalan.

Tabel komponen matrix pada hasil output SPSS terlihat bahwa tabel terbentuk 1 komponen, yang artinya indicator Keandalan 1, Keandalan 2 dan Keandalan 3 
dikatakan valid dan hanya menjelaskan faktor keandalan.

c. Uji validitas variabel Interaksi Pribadi.

Tabel komponen matrix pada hasil output SPSS terlihat bahwa tabel terbentuk 1 komponen, yang artinya indikator Interaksi Pribadi 1, Interaksi Pribadi 2 dan Interaksi Pribadi 3 dikatakan valid dan hanya menjelaskan faktor Interaksi Pribadi

d. Uji validitas variabel Pemecahan Masalah.

Tabel komponen matrix pada hasil output SPSS terlihat bahwa tabel terbentuk 1 komponen, yang artinya indikator Pemecahan Masalah 1, Pemecahan Masalah 2 dan Pemecahan Masalah 3 dikatakan valid dan hanya menjelaskan faktor Pemecahan Masalah.

e. Uji validitas variabel Kebijakan.

Tabel komponen matrix pada hasil output SPSS terlihat bahwa tabel terbentuk 1 komponen, yang artinya indikator Kebijakan 1, Kebijakan 2 dan Kebijakan 3 dikatakan valid dan hanya menjelaskan faktor Kebijakan.

f. Uji validitas variabel Kepuasan Konsumen.

Tabel komponen matrix pada hasil output SPSS terlihat bahwa tabel terbentuk 1 komponen, yang artinya indikator Kepuasan Konsumen 1, Kepuasan Konsumen 2 dan Kepuasan Konsumen 3 dikatakan valid dan hanya menjelaskan faktor Kepuasan Konsumen.
2. Hasil Uji Reliabilitas

\begin{tabular}{|l|l|l|l|}
\hline \multicolumn{1}{|c}{ Hasil Uji Realibilitas } \\
\hline Nama Variabel & $\begin{array}{l}\text { Nilai Cronbach's } \\
\text { Alpha }\end{array}$ & Nilai Kritis & Keterangan \\
\hline Aspek Fisik & 0,811 & 0,60 & Reliabel \\
\hline Keandalan & 0,647 & 0,60 & Reliabel \\
\hline Interaksi Pribadi & 0,702 & 0,60 & Realiabel \\
\hline $\begin{array}{l}\text { Pemecahan } \\
\text { Masalah }\end{array}$ & 0,583 & 0,60 & Tidak Reliabel \\
\hline Kebijakan & 0,582 & 0,60 & Tidak Reliabel \\
\hline $\begin{array}{l}\text { Kepuasan } \\
\text { Konsumen }\end{array}$ & 0,828 & 0,60 & Reliabel \\
\hline
\end{tabular}

a. Bahwa variabel Aspek Fisik indikator memiliki nilai Cronbach's Alpha 0.811yaitu lebih besar dari 0.60 berdasarkan ketentuan di atas maka indikator-indikator dalam variabel Aspek Fisik dikatakan reliabel.

b. Bahwa variabel Keandalan indikator memiliki nilai Cronbach's Alpha 0.647 yaitu lebih besar dari 0.60 berdasarkan ketentuan di atas maka indikator-indikator dalam variabel Keandalan dikatakan reliabel.

c. Bahwa variabel Interaksi Pribadi indikator memiliki nilai Cronbach's Alpha 0.702 yaitu lebih besar dari 0.60 berdasarkan ketentuan di atas maka indikator-indikator dalam variabel Interaksi Pribadi dikatakan reliabel.

d. Bahwa variabel Pemecahan Masalah indikator memiliki nilai Cronbach's Alpha0.583 yaitu lebih kecil dari 0.60 berdasarkan ketentuan diatas maka indikator-indikator dalam variabel Pemecahan Masalah tidak reliabel tetapi variabel ini tetap dipergunakan meskipun tidak reliabel, karena variabel ini penting dan valid.

e. Bahwa variabel Kebijakan indikator memiliki nilai Cronbach's Alpha 0.563 yaitu lebih kecil dari 0.60 berdasarkan ketentuan di atas maka indikator-indikator dalam variabel Kebijakan tidak reliabel tetapi variabel ini tetap dipergunakan meskipun tidak reliabel, karena variabel ini penting dan valid. 
f. Bahwa variabel Kepuasan Konsumen indikator memiliki nilai Cronbach's Alpha0.828 yaitu lebih besar dari 0.60 berdasarkan ketentuan di atas maka indikatorindikator dalam variabel Kepuasan Konsumen dikatakan reliabel.

3. Hasil Uji Regresi Linier Berganda Hasil Uji Regresi (Koefisien Regresi)

\begin{tabular}{|c|c|c|c|c|c|}
\hline \multirow[t]{2}{*}{ Model } & \multicolumn{2}{|c|}{$\begin{array}{l}\text { Unstandardized } \\
\text { Coeffisient }\end{array}$} & \multirow{2}{*}{$\begin{array}{c}\begin{array}{c}\text { Standartdized } \\
\text { Coeffisien }\end{array} \\
\text { Beta }\end{array}$} & \multirow[t]{2}{*}{$\mathrm{t}$} & \multirow[t]{2}{*}{ Sig } \\
\hline & B & Std. Eror & & & \\
\hline 1 (constant) & & & & & \\
\hline Aspek Fisik & $-1.350 \mathrm{E}-16$ & .067 & & .000 & 1.000 \\
\hline Keandalan & & .079 & .080 & 1.008 & .316 \\
\hline Interaksi & & .090 & .231 & 2.576 & .012 \\
\hline Pribadi & .159 & .087 & .159 & 1.818 & .072 \\
\hline Pemecahan & & & & & \\
\hline $\begin{array}{l}\text { Masalah } \\
\text { Kebijakan }\end{array}$ & $\begin{array}{l}.241 \\
.267\end{array}$ & $\begin{array}{l}.087 \\
.092\end{array}$ & .241 & $\begin{array}{l}2.778 \\
2.894\end{array}$ & $\begin{array}{l}.007 \\
005\end{array}$ \\
\hline Ketijakan & .201 & .092 & & & \\
\hline
\end{tabular}

$\mathrm{Y}=-1.350 \mathrm{E}-16+0.080 \mathrm{X} 1+0.231 \mathrm{X} 2+$ $0.159 \mathrm{X} 3+0.241 \mathrm{X} 4+0.267 \mathrm{X} 5$

Dari hasil persamaan regresi linier berganda tersebut, dapat diinterpresikan sebagai berikut:

$\mathrm{a}=-1.350 \mathrm{E}-16$ merupakan nilai konstanta, jika nilai X1, X2, X3, $\mathrm{X} 4$, dan X5 dianggap 0 maka akan menurunkan nilai kepuasan sebesar 0.000

$\mathrm{b} 1=0.080$ artinya variabel aspek fisik berpengaruh positif terhadap kepuasan konsumen dan apabila variabel aspek fisik meningkat 1 satuan, maka nilai aspk fisik akan meningkat 0.080. Semakin tinggi kenaikan variabel aspek fisik maka semakin tinggi pula pengaruh peningkatan kepuasan konsumen.

$\mathrm{b} 2=0.231$ artinya variabel keandalan berpengaruh positif terhadap kepuasan konsumen dan apabila variabel keandalan meningkat 1 satuan, maka nilai keandalanakan meningkat 0.231 . Semakin tinggi kenaikan variabel keandalan maka semakin tinggi pula pengaruh peningkatan kepuasan konsumen.

b3 $=0.159$ artinya variabel interaksi pribadi berpengaruh positif terhadap kepuasan konsumen dan apabila variabel interaksi pribadi meningkat 1 satuan, maka nilai interaksi pribadi akan meningkat 0.159. Semakin tinggi kenaikan variabel interaksi pribadi maka semakin tinggi pula pengaruh peningkatan kepuasan konsumen.

b4 $=0.241$ artinya variabel pemecahan masalah berpengaruh positif terhadap kepuasan konsumen dan apabila variabel pemecahan masalah meningkat 1 satuan, maka nilai pemecahan masalah akan meningkat 0.241. Semakin tinggi kenaikan variabel pemecahan masalah maka semakin tinggi pula pengaruh peningkatan kepuasan konsumen.

b5 $=0.267$ artinya variabel kebijakan berpengaruh positif terhadap kepuasan konsumen dan apabila variabel kebijakan meningkat 1 satuan, maka nilai kebijakan meningkat 0.267. Semakin tinggi kenaikan variabel kebijakan maka semakin tinggi pula pengaruh peningkatan kepuasan konsumen.

4. Hasil Uji Parsial (Uji T)

Hasil Uji Signifikansi Parsial (Uji t)

\begin{tabular}{|l|c|}
\hline \multicolumn{1}{|c|}{ Variabel } & Hasil Uji \\
\cline { 2 - 2 } & Signifikansi \\
\hline Aspek Fisik & 0.316 \\
\hline Keandalan & 0.012 \\
\hline Interaksi Pribadi & 0.072 \\
\hline Pemecahan Masalah & 0.007 \\
\hline Kebijakan & 0.005 \\
\hline
\end{tabular}

a. Variabel Aspek Fisik

Hasil pengujian dengan SPSS untuk variabel aspek fisik diperoleh nilai $\mathrm{t}$ hitung $=1.008$ tingkat signifikasi 0.316. Dengan menggunakan batas signifikansi $(\alpha)$ $=0.05$ maka nilai batas signifikansi $\alpha(0.05)<0.316$ maka hipotesis ditolak. Hal ini berarti variabel aspek fisik (X1) tidak mempunyai pengaruh terhadap kepuasan konsumen (Y).

b. Variabel Keandalan

Hasil pengujian dengan SPSS untuk variabel keandalan diperoleh nilai $\mathrm{t}$ hitung $=2.576$ tingkat signifikasi 0.012. Dengan menggunakan batas signifikansi $(\alpha)$ $=0.05$ maka nilai batas signifikansi $\alpha(0.05)>0.012$ maka hipotesis 
diterima. Hal ini berarti variabel keandalan (X2) mempunyai pengaruh terhadap kepuasan konsumen (Y).

c. Variabel Interaksi Pribadi

Hasil pengujian dengan SPSS untuk variabel interaksi pribadi diperoleh nilai $\mathrm{t}$ hitung $=1.818$ tingkat signifikasi 0.072. Dengan menggunakan batas signifikansi $(\alpha)$ $=0.05$ maka nilai batas signifikansi $\alpha(0.05)<0.072$ maka hipotesis ditolak. Hal ini berarti variabel interaksi pribadi (X3) tidak mempunyai pengaruh terhadap kepuasan konsumen (Y).

d. Variabel Pemecahan Masalah

Hasil pengujian dengan SPSS untuk variabel pemecahan masalah diperoleh nilai $\mathrm{t}$ hitung $=2.778$ tingkat signifikasi 0.007 . Dengan menggunakan batas signifikansi $(\alpha)$ $=0.05$ maka nilai batas signifikansi $\alpha(0.05)>0.007$ maka hipotesis diterima. Hal ini berarti variabel pemecahan masalah (X4) mempunyai pengaruh terhadap kepuasan konsumen (Y).

e. Variabel Kebijakan

Hasil pengujian dengan SPSS untuk variabel kebijakan diperoleh nilai $\mathrm{t}$ hitung $=2.894$ tingkat signifikasi 0.005 . Dengan menggunakan batas signifikansi $(\alpha)$ $=0.05$ maka nilai batas signifikansi $\alpha(0.05)>0.005$ maka hipotesis diterima. Hal ini berarti variabel kebijakan (X5) mempunyai pengaruh terhadap kepuasan konsumen (Y).

5. Hasil Uji Simultan (Uji F)

\begin{tabular}{|c|c|c|c|c|c|}
\hline \multicolumn{6}{|c|}{ Hasil Uji Signifikansi Simultan (Uji F) } \\
\hline Model & $\begin{array}{l}\text { Sum of } \\
\text { Squares }\end{array}$ & Df & $\begin{array}{c}\text { Mean } \\
\text { Square }\end{array}$ & $\mathrm{F}$ & Sig. \\
\hline $\begin{array}{l}1 \text { Regression } \\
\text { Residual } \\
\text { Total }\end{array}$ & $\begin{array}{l}56.586 \\
42.414 \\
99.000\end{array}$ & \begin{tabular}{|l|}
5 \\
94 \\
99
\end{tabular} & $\begin{array}{l}11.317 \\
.451\end{array}$ & 25.081 & $.000^{\mathrm{a}}$ \\
\hline
\end{tabular}

Berdasarkan hasil uji simultan dari tabel di atas ditunjukan bahwa $\mathrm{F}$ hitung sebesar 25.081 dan pada uji $\mathrm{F}$ diatas didapatkan dengan taraf signifikansi $0.05(\operatorname{sig} \alpha 0.000<0.05)$ dapat disimpulkan bahwa faktor Aspek Fisik (X1), Keandalan (X2), Interaksi Pribadi (X3), Pemecahan Masalah (X4) dan Kebijakan (X5) secara bersama-sama memiliki pengaruh yang signifikan terhadap kepuasan konsumen (Y).

\section{Hasil Uji Koefisien Determinasi \\ Hasil Uji Regresi (Koefisien Determinasi)}

\begin{tabular}{|c|c|c|c|c|}
\hline Model & R & R Square & Adjusted R Square & Std.Error of the Estimate \\
\hline 1 & $.756^{\mathrm{a}}$ & .572 & .549 & .67172579 \\
\hline
\end{tabular}

Pada tabel di atas dapat dilihat bahwa nilai $\mathrm{R}^{2}$ adalah sebesar 0.572 . Hal ini dapat diartikan bahwa variabel independen Aspek Fisik (X1), Keandalan (X2), Interaksi Pribadi (X3), Pemecahan Masalah (X4) dan Kebijakan (X5) dapat menjelaskan variabel dependen kepuasan (Y) sebesar $57,2 \%$. Sedangkan sisanya diterangkan oleh faktor lain yang tidak diteliti.

\section{Pembahasan}

Pernyataan hipotesis pertama bahwa variabel Aspek Fisik berpengaruh negatif dan signifikan terhadap kepuasan konsumen. Hal ini bisa ditunjukan dengan nilai signifikansi ( $\mathrm{P}$ Value) sebesar 0.316 diatas 0.05 serta nilai koefisien regresi sebesar 0.080. Dapat disimpulkan bahwa variabel Aspek Fisik berpengaruh negatif dan signifikan terhadap kepuasan konsumen.

Pernyataan hipotesis kedua bahwa variabel Keandalan berpengaruh positif tetapi tidak signifikan terhadap kepuasan konsumen. Hal ini bisa ditunjukan dengan nilai signifikansi (P Value) sebesar 0.012 di bawah 0.05 serta nilai koefisien regresi sebesar 0.231. Dapat disimpulkan bahwa variabel Keandalan berpengaruh positif tetapi tidak signifikan terhadap kepuasan konsumen.

Pernyataan hipotesis ketiga bahwa variabel Interaksi Pribadi berpengaruh negatif tetapi tidak signifikan terhadap 
kepuasan konsumen. Hal ini bisa ditunjukan dengan nilai signifikansi ( $\mathrm{P}$ Value) sebesar 0.072 yang lebih besar dari 0.05 serta nilai koefisien regresi sebesar 0.159. Dapat disimpulkan bahwa variabel Interaksi Pribadi berpengaruh positif tetapi tidak signifikan terhadap kepuasan konsumen.

Pernyataan hipotesis keempat bahwa variabel Pemecahan Masalah berpengaruh positif dan signifikan terhadap kepuasan konsumen. Hal ini bisa ditunjukan dengan nilai signifikansi (P Value) sebesar 0.007 yang lebih kecil 0.05 serta nilai koefisien regresi sebesar 0.241. Dapat disimpulkan bahwa variabel Pemecahan Masalah berpengaruh positif dan berpengaruh signifikan terhadap kepuasan konsumen.

Pernyataan hipotesis kelima bahwa variabel Kebijakan berpengaruh positif dan signifikan terhadap kepuasan konsumen. Hal ini bisa ditunjukan dengan nilai signifikansi (P Value) sebesar 0.005 yang jauh di bawah 0.05 serta nilai koefisien regresi sebesar 0.267. Dapat disimpulkan bahwa variabel Kebijakan berpengaruh positif dan signifikan terhadap kepuasan konsumen.

\section{KESIMPULAN DAN SARAN}

\section{Kesimpulan}

1. Variabel aspek fisik berpengaruh negatif dan signifikan terhadap kepuasan konsumen. Hal ini bisa ditunjukan dengan nilai signifikansi $(\mathrm{P}$ Value) sebesar 0.316 diatas 0.05 serta nilai koefisien regresi sebesar 0.080. Dapat disimpulkan bahwa variabel aspek fisik berpengaruh negatif dan signifikan terhadap kepuasan konsumen.

2. Variabel keandalan berpengaruh positif tetapi tidak signifikan terhadap kepuasan konsumen. Hal ini bisa ditunjukan dengan nilai signifikansi $(\mathrm{P}$ Value) sebesar 0.012 dibawah 0.05 serta nilai koefisien regresi sebesar
0.231. Dapat disimpulkan bahwa variabel keandalan berpengaruh positif tetapi tidak signifikan terhadap kepuasan konsumen.

3. Variabel interaksi pribadi berpengaruh negatif tetapi tidak signifikan terhadap kepuasan konsumen. Hal ini bisa ditunjukan dengan nilai signifikansi ( $P$ Value) sebesar 0.072 yang lebih besar dari 0.05 serta nilai koefisien regresi sebesar 0.159. Dapat disimpulkan bahwa variabel interaksi pribadi berpengaruh positif tetapi tidak signifikan terhadap kepuasan konsumen.

4. Variabel pemecahan masalah berpengaruh positif dan signifikan terhadap kepuasan konsumen. Hal ini bisa ditunjukan dengan nilai signifikansi (P Value) sebesar 0.007 yang lebih kecil 0.05 serta nilai koefisien regresi sebesar 0.241. Dapat disimpulkan bahwa variabel pemecahan masalah berpengaruh positif dan berpengaruh signifikan terhadap kepuasan konsumen.

5. Variabel kebijakan berpengaruh positif dan signifikan terhadap kepuasan konsumen. Hal ini bisa ditunjukan dengan nilai signifikansi ( $\mathrm{P}$ Value) sebesar 0.005 yang jauh dibawah 0.05 serta nilai koefisien regresi sebesar 0.267. Dapat disimpulkan bahwa variabel Kebijakan berpengaruh positif dan signifikan terhadap kepuasan konsumen.

\section{Saran}

1. Swalayan Citrouli Babarsari Yogyakarta harus tetap mempertahankan tingkat Kepuasan konsumen karena terbukti pada hasil penelitian bahwa tingkat Kepuasan konsumen terhadap Swalayan Citrouli Babarsari Yogyakarta tinggi dengan demikian Kepuasan konsumen dapat dipertahankan. 
2. Untuk konsumen Swalayan Citrouli Babarsari Yogyakarta hendaknya lebih selektif dan objektif dalam menilai, memilih dan menggunakan pelayanan Swalayan Citrouli Babarsari Yogyakarta.

\section{DAFTAR PUSTAKA}

Algifari. (2000). Analisis Regresi, Teori, Kasus \& Solusi. Yogyakarta: BPFE UGM.

Hidayat, Aziz Alimul. (2009). Metode Penelitian Keperawatan dan Teknik Analisis Data. Jakarta: Salemba Medika.

Lovelock, Christoper dan Lauren K Wright. (2007). Manajemen Pemasaran Jasa. Jakarta: PT. Indeks.

Lupiyoadi, Rambat dan Hamdani, A. (2006). Manajemen Pemasaran Jasa. Edisi Kedua. Jakarta: Salemba Empat.

Lupiyoadi, Rambat dan Hamdani, A. (2008). Manajemen Pemasaran Jasa. Edisi Kedua Cetakan Keempat. Jakarta: Salemba Empat.

Kasmir. (2005). Bank dan Lembaga Keuangan Lainnya. Jakarta: PT Raja Grafindo.

Kotler, Philip. (2007). Manajemen Pemasaran: Analisis Perencanaan, Pengendalian. Prentice Hall Edisi Bahasa Indonesia. Jakarta: Salemba Empat.

Sugiyono. (2008). Metode Penelitian Kunatitatif Kualitatif dan $R \& D$. Bandung: Alfabeta.

Sugiyono. (2014). Metode Penelitian Kuantitatif dan Kombinasi (Mixed Methods). Bandung: Alfabeta. 